\title{
Color Doppler ultrasonography in detecting transdiaphragmatic flow of hepatic hydrothorax: Correlation with thoracoscopic findings
}

\author{
Pei-Ming Huang, MD, Yin-Yi Han, MD, Shuenn-Wen Kuo, MD, and Yung-Chie Lee, MD, PhD, Taipei, \\ Taiwan
}

\begin{abstract}
Many mechanisms have been proposed for hepatic hydrothorax $(\mathrm{HH})$, pleural effusion seen in cirrhotic patients, and the transdiaphragmatic flow of ascitic fluid through the diaphragmatic defects is considered the most probable. $^{1,2}$ There are several methods for diagnosis of $\mathrm{HH}$, including biochemical analysis of ascitic and pleural fluids, conventional radiography, radioisotopic imaging, magnetic resonance imaging, and thoracoscopy. Among these, ultrasonography may be considered the easiest method and has the benefit of real-time diagnosis of anatomic integrity. On the other hand, the magnification offered by the optical system of thoracoscopy allows excellent localization of diaphragmatic defects. This study is the first demonstration of the transdiaphragmatic flow by color Doppler ultrasonography that further directly verifies detected defects by means of video-assisted thoracoscopic surgery.
\end{abstract}

\section{MATERIALS AND METHODS}

Between January 2005 and August 2007, a total of 9 patients with cirrhosis and refractory pleural effusion (4 male and 5 female; mean age, 59 years; range, $41-81$ years) were evaluated to determine the communication of fluid between peritoneal and pleural cavities. Statements of patient consent and the approval of internal review boards were all obtained before further investigation. The pleural effusion volume was estimated from chest radiography and was subsequently studied with color Doppler ultrasonography (Sonos 5500 with 3-MHz curved linear transducers; Agilent Technologies, Andover, Mass) in the supine position before and after diagnostic thoracocentesis. Other maneuvers (increasing abdominal pressure, Valsalva maneuver) were applied during the interrogation. Moreover, the types of diaphragmatic defects were further compared with the findings of video-assisted thoracoscopic surgery in all patients. The channels between the pleural and abdominal cavities were interrupted with the Mersilene mesh (Ethicon Ltd, Edinburgh, UK) onlay method ${ }^{3}$ by means of videothoracoscopy through three trocar sites. The characteristics of all patients, ultrasonographic findings, and videothoracoscopic findings are described in Table 1 .

\section{RESULTS}

On color Doppler ultrasonography, peritoneopleural communication, marked by jet flow from the peritoneal

\footnotetext{
From the Department of Traumatology and Surgery, National Taiwan University Hospital and National Taiwan University College of Medicine, Taipei, Taiwan.

Received for publication April 3, 2008; accepted for publication April 16, 2008; available ahead of print Sept 9, 2008.

Address for reprints: Yung-Chie Lee, MD, PhD, Division of Thoracic Surgery, Department of Surgery and Traumatology, National Taiwan University Hospital, No. 7, Chung-Shan S Rd, Taipei 100, Taiwan (E-mail: yclee@ntuh.gov.tw). J Thorac Cardiovasc Surg 2009;138:1251-2

0022-5223/\$36.00

Copyright (c) 2009 by The American Association for Thoracic Surgery doi:10.1016/j.jtcvs.2008.04.031
}

to the pleural space (Figure 1), was displayed in 5 of 9 patients. Mean of maximum flow velocity was $15.89 \mathrm{~cm} / \mathrm{s}$ (range, 6.9-27.8 cm/s; Table 1). Transdiaphragmatic flow became obvious after thoracocentesis in 1 patient with massive pleural effusion. Among the patients with positive findings of color Doppler ultrasonography, all had bleb defects on the tendinous area of the diaphragm. Color Doppler ultrasonography did not, however, demonstrate transdiaphragmatic flow in the oozing type of diaphragmatic defect in this study, even though the radiologic study showed massive pleural effusion. Moreover, some defects themselves may have been too small to detect or may have been present only transiently. Thus no transdiaphragmatic flow was noted by color Doppler ultrasonography even for bleb defects noted on the diaphragm by videothoracoscopy in 2 cases.

\section{DISCUSSION}

The pathogenesis of $\mathrm{HH}$ may involve microscopic or macroscopic diaphragmatic defects. Demonstration of the presence or absence of such communications is helpful in therapeutic decision making. These findings of color Doppler ultrasonography contribute to the explanation of the mechanism of $\mathrm{HH}$, movement of fluid from the peritoneal to the pleural cavity. Biochemical analysis of ascitic and pleural fluids only provides indirect information about the origin of the effusion and cannot confirm the peritoneopleural communication of $\mathrm{HH}^{4}$ Dyes, air, and radioisotopes ${ }^{5}$ have all been used to demonstrate the transdiaphragmatic passage of ascitic fluid into the pleural space. All involve invasive and time-consuming procedures, however, and require delayed and multiple images. In addition, the size of the radiopharmaceutical particle selected will also determine the transdiaphragmatic migration pattern, with a correct diagnostic rate around $80 \%$ to $90 \% .^{5}$ Moreover, radionuclide detection is generally unsuccessful in nonascitic cases of HH. In this study, the pulsed-wave Doppler profile of the bleb defect revealed low density and to-and-fro transdiaphragmatic flow, which were different from high-velocity triphase or continuous flow of the branched diaphragmatic vessels. Such flow could explain why in several published cases of anascitic $\mathrm{HH}^{5}$ the transdiaphragmatic effusion still bothered the patient.

Once the communication has been adequately demonstrated, placement of a chest tube, which usually results into hypoalbuminemia and malnutrition, can be avoided 
TABLE 1. Clinical and demographic characteristics of patients with hepatic hydrothorax

\begin{tabular}{|c|c|c|c|c|c|c|c|}
\hline Case & Age $(y)$ & Sex & Etiology of cirrhosis & $\begin{array}{l}\text { Ascites, chest } \\
\text { plain film study }\end{array}$ & $\begin{array}{c}\text { Color } \\
\text { Doppler }\end{array}$ & $\begin{array}{l}\text { Operative } \\
\text { findings }\end{array}$ & $\begin{array}{c}\text { Spectral Doppler } \\
\text { waveform }\end{array}$ \\
\hline 1 & 41 & M & Alcoholic LC & Present, rt 2/3 hemithorax & Obvious & Blebs & To-and-fro, $\mathrm{V}_{\max } 9.3 \mathrm{~cm} / \mathrm{s}$ \\
\hline 2 & 77 & M & HCV LC & Present, $\mathrm{rt}^{1} / 4$ Hemithorax & Present & Blebs & $\begin{array}{l}\text { To-and-fro, } \mathrm{V}_{\max } 20.1 \\
\mathrm{~cm} / \mathrm{s}\end{array}$ \\
\hline 3 & 57 & M & Primary biliary LC & Absent, $\mathrm{rt}^{1} / 2$ hemithorax & Absent & Oozing & Absent \\
\hline 4 & 81 & $\mathrm{~F}$ & Cryptogenic LC & Absent, $\mathrm{rt}^{1} / 2$ hemithorax & Present & Blebs & $\begin{array}{l}\text { To-and-fro, } V_{\max } 27.8 \\
\mathrm{~cm} / \mathrm{s}\end{array}$ \\
\hline 5 & 62 & $\mathrm{~F}$ & HCV LC & Present, $\mathrm{rt}^{1} / 4$ hemithorax & Present & Blebs & $\begin{array}{l}\text { To-and-fro, } \mathrm{V}_{\max } 15.2 \\
\mathrm{~cm} / \mathrm{s}\end{array}$ \\
\hline 6 & 64 & $\mathrm{~F}$ & HBV LC & Present, $\mathrm{rt}^{1} / 4$ hemithorax & Absent & Blebs & Absent \\
\hline 7 & 58 & $\mathrm{~F}$ & HBV LC & Absent, $\mathrm{rt}^{1} / 4$ hemithorax & Absent & Oozing & Absent \\
\hline 8 & 49 & M & Alcoholic LC & $\begin{array}{l}\text { Present, bilateral, } \mathrm{rt}^{1} / 4 \\
\text { hemithorax }\end{array}$ & Absent & Blebs & Absent \\
\hline 9 & 43 & $\mathrm{~F}$ & HBV and alcoholic LC & Absent, $\mathrm{rt}^{1} / 2$ hemithorax & Present & Blebs & To-and-fro, $\mathrm{V}_{\max } 6.9 \mathrm{~cm} / \mathrm{s}$ \\
\hline
\end{tabular}

$M$, Male; $L C$, liver cirrhosis, $r t$, right; $V_{\max }$, maximum velocity; $H C V$, hepatitis $\mathrm{C}$ virus; $F$, female; $H B V$, hepatitis $\mathrm{B}$ virus.
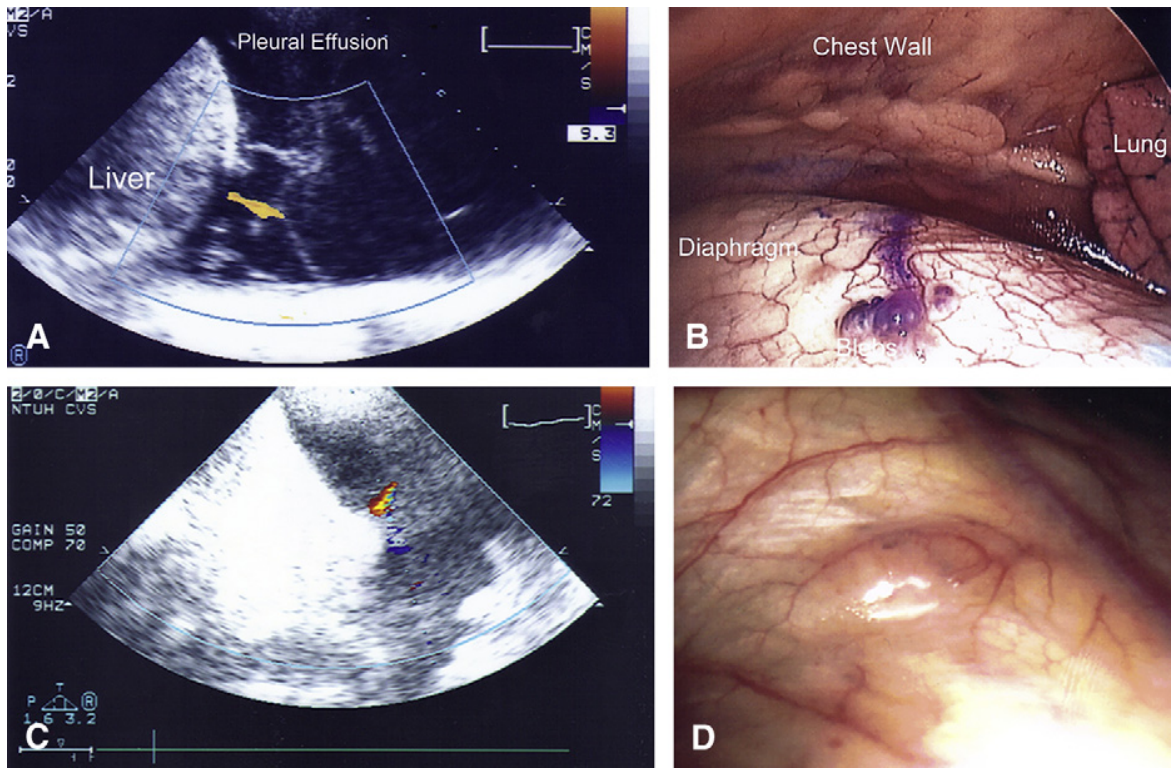

FIGURE 1. A, Color Doppler ultrasonography shows transdiaphragmatic flow correlating with operative findings. B, Photograph of cluster of diaphragmatic blebs identified by videothoracoscopy after intraoperative injection of dilute methylene blue into abdomen. $\mathrm{C}$ and $\mathrm{D}$, Color-encoding image can be found at eminent diaphragmatic defect.

and treatment directed toward diaphragmatic repair through videothoracoscopy, because the defect is usually large. If an ultrasonographic diagnostic method fails to detect any defect, it seems reasonable in this situation to perform conservative treatment, such as chemical pleurodesis, continuous positive-airway pressure ventilation, or diuretic administration, because the diaphragmatic defect is small. In conclusion, color Doppler ultrasonography exposes patients with $\mathrm{HH}$ to a minimal amount of radiation and can be performed dynamically to confirm the transdiaphragmatic movement of ascitic fluid into the pleural cavity.

\section{References}

1. Garcia N Jr, Mihas AA. Hepatic hydrothorax: pathophysiology, diagnosis, and management. J Clin Gastroenterol. 2004;38:52-8.

2. Huang PM, Chang YL, Yang CY, Lee YC. The morphology of diaphragmatic defects in hepatic hydrothorax: thoracoscopic finding. $J$ Thorac Cardiovasc Surg. 2005; 130:141-5.

3. Takayama T, Kurokawa Y, Kaiwa Y, Ansai M, Chiba T, Inoue T, et al. A new technique of thoracoscopic pleurodesis for refractory hepatic hydrothorax. Surg Endosc. 2004; 18:140-3.

4. Ackerman Z, Reynolds TB. Evaluation of pleural fluid in patients with cirrhosis. J Clin Gastroenterol. 1997;25:619-22.

5. Bhattacharya A, Mittal BR, Biswas T, Dhiman RK, Singh B, Jindal SK, et al. Radioisotope scintigraphy in the diagnosis of hepatic hydrothorax. J Gastroenterol Hepatol. 2001;16:317-21. 